\title{
O MAL-ESTAR NA COMUNICAÇÃO: A VIOLAÇÃO DA OPINIÃO PÚBLICA PELO SISTEMA MIDIÁTICO BRASILEIRO
}

\author{
COMMUNICATION AND ITS DISCONTENTS: \\ THE VIOLATION OF PUBLIC OPINION BY THE BRAZILIAN \\ MEDIA SYSTEM
}

\section{Luciana Salazar Salgado* Jaime Tadeu Oliva**}

\section{RESUMO}

Este artigo, de orientação fundamentalmente teórica, documenta discussões interdisciplinares sobre mídia que põem a comunicação no centro do debate sobre as democracias contemporâneas. Partindo de um quadro de estudos que define o discurso como encontro da língua com as instituições, aqui especificado pela perspectiva mediológica, convocamos as noções de sistema e de mundo da vida para expor a tensão condicionante das funções atribuídas e das funções assumidas pelo que costuma ser referido por "mídia" no atual período, em especial na sua relação com a política. Isso implica noções fundamentais para as ciências humanas e sociais como intersubjetividade, vontade política e opinião pública. Propomos, portanto, uma reflexão sobre os imaginários relativos à mídia, sobre as práticas que lhes dão sustentação e, finalmente, sobre o deslizamento que se estabelece nas atuais condições de produção das "trocas" comunicacionais, as quais supostamente estão na base dos direitos humanos, supostamente garantidores das democracias, definidores de seus cidadãos. Aspectos da atual conjuntura brasileira são postos em foco.

Palavras-chave: mídium; mundo da vida; opinião pública.

\section{ABSTRACT}

This article, a theoretical proposal, features an interdisciplinary discussion about media that puts communication at the center of the debate on contemporary democracies. From a well-established framework of studies that defines discourse as the encounter between language and institutions, here specified by the mediological perspective, we rely on the concepts of system and lifeworld to expose the conditioning tensions of the assigned and the assumed functions of what is usually referred by "media" in the current period, especially in its relation to politics. This implies fundamental notions for the human and social sciences as intersubjectivity and public opinion. We propose an argument on the imagery related to the media, on the practices that sustain it, and finally on the slipping movement that

\footnotetext{
* Universidade Federal de São Carlos, São Carlos (SP), Brasil. lucianasalazarsalgado@gmail.com

** Universidade de São Paulo, São Paulo (SP), Brasil. itoliva@gmail.com
} 
is established in the current conditions of the communicational "exchange", which are supposed to be the basis of human rights, witch are supposed to be, on its turn, a warranty of democracy, of its citizens. We focus here some aspects of the Brazilian context.

Keywords: mídium; lifeworld; publicopinion.

\section{INTRODUÇÃO AO PROBLEMA}

Em 2012, o Instituto de Estudos Brasileiros (IEB/USP) comemorava seus cinquenta anos de fundação, oportunidade na qual foi lançado o projeto Como Pensar o Brasil hoje, e naquela ocasião o tema "sistema midiático" foi definido como central, mesmo que sua presença saliente e controversa já naquele ano não tivesse nem de longe atingido o paroxismo que marcará seu funcionamento a partir de 2014. Considerando as discussões havidas desde então, que estabeleceu, para muitos, a posição de que não há mais como interpretar a situação política e social do país sem levar em conta o protagonismo do sistema midiático, propomos o entendimento de que aí se revela uma contradição muito esclarecedora: da mediação ao ativismo, percebe-se um deslizamento perturbador nas funções desse sistema.

Para examinar, de uma perspectiva discursiva, o regime de funcionamento que define esse sistema, assumimos aqui a abordagem medialógica ${ }^{1}$, isto é, o entendimento de que esse sistema de distribuição dos discursos é composto por matrizes de sociabilidade (corporações de notícia, agências, blogosfera, jornalismo livre, etc.) que encarnam vetores de sensibilidade (gêneros do discurso inscritos em materialidades diversas, impressas, eletrônicas e digitais). Nos termos de Debray (2000a, 2000b), trata-se de operar com as relações entre matéria organizada (MO), isto é, os objetos técnicos em que se inscrevem os textos ou, mais precisamente, em que se atualizam os discursos, e a organização materializada (OM), isto é, os modos de fazer circular e de, nessa circulação, distribuir textos, discursos e, portanto, poderes instituídos. Assim, podemos entender doravante que o termo sistema midiático refere um conjunto de mídiuns ( $\mathrm{MO} / \mathrm{OM})$, em seus componentes tecnológicos e institucionais, constitutivos da circulação de informações no seu modo de compor a comunicação social. E aqui cabe um esclarecimento: as informações factuais e opinativas são entendidas como objetos discursivos definidos no âmbito (principalmente) do jornalismo, com sua deontologia (Cf. Bertrand, 1999), enquanto a comunicação social abrange outros produtos culturais ligados

1. No Brasil, diversas traduções consagraram o termo "midialogia", mas é preciso frisar que a medialogia (médialogie, em francês) estuda as mediações e não as mídias propriamente, mas estas também se configuram como mídiuns (médiums, em francês) importantes na organização dos processos de transmissão de valores e crenças - objeto fundamental dessa perspectiva teórica. 
às artes e às várias formas de entretenimento, sendo que tal caracterização merece ressalvas diante dos limites borrados que não nos permitem distinguir com clareza onde termina o jornalismo e começa o entretenimento, por exemplo (Cf. JENKINS, GREEN, FORD, 2014). Assim, esse sistema complexo opera fundamentalmente com mensagens verbais e não verbais, frequentemente multimodais, e seus setores são o mercado editorial (edição), a imprensa escrita, a radiodifusão e a televisão (audiovisual). O cinema também se vincula a esse sistema com peculiaridades que não serão abordadas nesta ocasião. Importa dizer, ainda, que, em termos de atividades econômicas, não será exagero afirmar que esse sistema é um dos mais abrangentes e poderosos segmentos econômicos atuais.

Diante dessa abrangência e desse poderio econômico, nas ditas sociedades de massas contemporâneas, o sistema midiático é percebido como uma realidade autônoma, cuja função social é definida e construída pela lógica e a dinâmica interna do próprio sistema. Neste artigo, vamos nos concentrar na relação do sistema midiático com a política e como, nesse caso, a percepção de forte autonomia do sistema midiático é notada. A questão é: a mídia² é costumeiramente vista como uma exterioridade, que exerce uma influência, poderosa certamente, sobre o sistema político. Segundo essa visada, os diversos atores do sistema político, diante da força dessa influência, por vezes a instrumentalizariam (fala-se, então, em partidarização da mídia) e, em outras situações, gostariam de atenuar esse poder negativo (e, então, se pode falar em regulação, democratização da mídia, etc.) (Cf. entre outros, o banco de dados constituído pelo observatório Fórum Nacional pela Democratização da Comunicação - FNDC, disponível em http://fndc.org.br/. Acesso em: 10 mar. 2018).

Uma consequência imediata dessa condição de externalidade atribuída à mídia em relação à vida política se revela na maior parte das análises políticas profissionais, aquelas feitas pelos próprios jornalistas e por acadêmicos das ciências sociais - estes frequentemente convocados pela mídia, quando, afinal, suas análises

2. Devemos sublinhar que, quando se trata dessa relação, o sistema midiático é reduzido à noção de mídia, que se vincularia mais ao jornalismo praticado no sistema. O que não deixa de ser uma ingenuidade, pois outros "produtos midiáticos" também operam na política, direta ou indiretamente. Tereza Caldeira em 1991 escreve um artigo, já clássico, em que destaca o papel determinante de parte da mídia como importante veiculadora de um discurso anti-"direitos humanos de bandidos". Coisas como "defender essas pessoas é defender bandidos, é defender o crime", "direitos humanos para humanos direitos", "não se deve gastar dinheiro público com bandidos", "direitos humanos a bandidos gera impunidade" etc., associam-se a clamores por castigos e torturas e até pela pena de morte e também a exageros nas narrativas, são criações "clássicas" do sistema midiático brasileiro veiculadas em programas de entretenimento, de teledramaturgia e de "serviços". (Ver "Direitos Humanos ou 'privilégios de bandidos'? Desventuras da democratização brasileira. São Paulo: Novos Estudos Cebrap, julho de 1991, número 30, p. 1-13). 
se distribuem mais efetivamente. De fato, os jornalistas, eles próprios vetores de sensibilidade do sistema midiático, fazem questão de se situar fora da vida política, não falam do seu próprio papel e nem atribuem importância ao seu peso político. Eles seriam mediadores e não ativistas ${ }^{3}$. Por sua vez, os acadêmicos e as lideranças políticas estão evidentemente repensando o papel do sistema midiático, mas há indicativos de que o protagonismo desse sistema na vida política ainda não tem correspondência à altura nas análises políticas das ciências sociais e nem junto aos partidos que são, particularmente, alvos do sistema midiático. Essa é a opinião de João Feres Jr., mentor e animador do portal Manchetômetro ${ }^{4}$, cientista político particularmente atento à evolução dessas discussões no âmbito das pesquisas acadêmicas ${ }^{5}$. Não estamos em desacordo sobre a condição do sistema midiático como algo que tem certa externalidade em relação à vida política, mas os argumentos a propósito seguem outras lógicas. Aqui, proporemos uma reflexão sobre as condicionantes que constituem os imaginários relativos à mídia, as práticas que lhe dão sustentação e, finalmente, sobre o deslizamento que se estabelece nas atuais condições de produção. Nesta perspectiva, imaginários são, bem entendido, conjuntos semânticos compostos pela articulação de imagens (materializadas ou evocadas) numa dada conjuntura social, portanto histórica, formalizada em certos dispositivos e distribuída conforme as forças políticas oficiais e oficiosas que presidem uma dada conjuntura.

3. Na conjuntura brasileira atual, é muito provável que nos bastidores essa "humildade" não resista. Não faltam exemplos de irrupções incontroláveis de vaidade com o poder adquirido no quadro político atual. São comuns comemorações públicas de grupos de jornalistas que se enxergam como vitoriosos diante das consequências de suas práticas como jornalistas. Um registro resumitivo pode ser encontrado no post intitulado "Jornalistas da grande mídia comemoram nas redes aprofundamento do regime de exceção", disponível em https://www.ocafezinho.com/2018/01/25/. Acesso em: 10 mar. 2018.

4. "O Manchetômetro é um site de acompanhamento da cobertura da grande mídia sobre temas de economia e política produzido pelo Laboratório de Estudos de Mídia e Esfera Pública (LEMEP). O LEMEP tem registro no Diretório de Grupos de Pesquisa do CNPq e é sediado no Instituto de Estudos Sociais e Políticos (IESP) da Universidade do Estado do Rio de Janeiro (UERJ). O Manchetômetro não tem filiação com partidos ou grupos econômicos." Disponível em: http:// www.manchetometro.com.br/index.php/quem-somos-2/. Acesso em: 12 mar. 2018.

5. "O principal erro do PT, que causou sua derrota nas urnas, foi não ter atentado para a importância da comunicação pública para a formação de opinião dos cidadãos. Esse erro deve ser atribuído ao mesmo tipo de ingenuidade do carpidor, que naturaliza a questão do fluxo de informação em nossa sociedade, ou melhor dizendo, ignora suas especificidades. Enquanto as esquerdas estiverem capturadas por essas concepções pueris do jogo político, continuarão a sofrer repetidas derrotas." Disponível em https://jornalggn.com.br/blog/joao-feres-junior/o-erro-do-pt-e-a-corrupcao-porjoao-feres-junior. Acesso em : 12 mar. 2018. 


\section{O SISTEMA MIDIÁTICO NO COMPLEXO SOCIOPOLÍTICO}

A condição do sistema midiático como externalidade em relação às lides políticas está naturalizada (Cf., entre outros, o recente manual de Ringoot, de 2014). Em nosso país essa posição parece dominar: influencia, mas não pertence, pode estar politizado nesse momento, mas isso é uma anomalia, é abusivo. Essa é a posição dos jornalistas críticos e dissidentes, quando não marginalizados involuntariamente do sistema. De um modo geral, a crítica de esquerda também tende a desincorporar o sistema midiático da política corrente, tratando-o como externalidade, cuja função é produzir ideologia pró-capitalista. Ele seria, então, produto do capitalismo e existiria justamente para isso, e como tal visão é pacífica, o que mais importa é entender a política no capitalismo, a democracia burguesa e não seus "meros instrumentos", o que está a serviço dela. Uma ilustração forte desse posicionamento é a célebre afirmação de Gramsci, repetida ad nauseum:

Os jornais são aparelhos ideológicos cuja função é transformar uma verdade de classe num senso comum, assimilado pelas demais classes como verdade coletiva - isto é, exerce o papel cultural de propagador de ideologia. Ela embute uma ética, mas também a ética não é inocente: ela é uma ética de classe. ${ }^{6}$

Por fim, constata-se, ainda, que o sistema midiático é visto desse modo também por notáveis intelectuais de projeção pública ${ }^{7}$. Assim, o sistema midiático parece insuscetível às funções e práticas democráticas, às influências das dinâmicas políticas, pois ele se materializa formalmente em uma arquitetura programada e cristalizada, vinculada a uma missão ideológica incontornável.

Esse lugar do sistema midiático fora do sistema político tout court, tem um contraponto histórico e oposto na ideologia liberal que nasce da revolução norteamericana. Thomas Jefferson, assim como Thomas Paine, concebe a formação de um consenso político, logo da vontade política, em meio à discussão pública

6. Essa passagem é tão retomada, já destacada do texto original, que a citamos aqui em sua circulação atual, não necessariamente fidedigna - o que em si é um dado. Em todo caso, importa o fato de que é muito esgrimida e vem com a chancela de Gramsci, basta acionar qualquer buscador na internet para ver que essa citação se multiplica em centenas de artigos. Ver, por exemplo, no Observatório da Imprensa, onde reaparece com alguma frequência, no artigo de Jota Alcides, de 2015, disponível em http://observatoriodaimprensa.com.br/feitos-desfeitas/revolucao-gramsciana/, último acesso 10 mar. 2018.

7. Emblemático é o caso do jurista Fábio Konder Comparato que, com certo tédio, tem afirmado em sucessivas aparições públicas que o papel da mídia é difundir o poder ideológico do capitalismo; que os meios de comunicação são controlados pelos interesses capitalistas, etc. Para um registro recente de suas formulações, ver entrevista concedida ao jornalista Paulo Henrique Amorim, disponível em https://www.youtube.com/watch?v=ERKusMy0wL0Acesso em: 10 mar. 2018. 
propiciada pela comunicação social. Jefferson não crê em virtudes emancipadoras de uma máquina legislativa, instaurando leis. Tem menos confiança no Estado do que na sociedade ela mesma, para realizar a emancipação dos cidadãos. Diante de uma sociedade provida de Estado mas desprovida de jornais, ele sem dúvida preferiria uma sociedade sem Estado mas com uma imprensa livre (FERRY, 2005). Evidentemente, a opinião pública formada na relação com a imprensa livre (contemporaneamente, seu desdobramento é o sistema midiático) tem um grande peso. Desse modo, vê-se que a imprensa está no centro da vida política e totalmente vinculada à formação da vontade política, e não se trata de uma externalidade que se relaciona com essa formação quase como uma intrusa.

Dito isso, temos em vista a atual conjuntura de um motor único materializado em uma unicidade técnica que suscita uma experiência de ubiquidade sem precedentes, tecida pelo que Santos (2000) chama de cognoscibilidade planetária e convergência dos momentos, condicionantes produzidas fundamentalmente pela ampla circulação de informação selecionada. E, nessa conjuntura, nos parece evidente que a visão liberal clássica acerta ao perceber que, nas sociedades de massas que se inauguravam, o complexo sociopolítico que estruturará o sistema democrático incluirá em suas entranhas os mecanismos técnicos e normativos de formação do que passará a ser referido por opinião pública - de fato, um produto do sistema midiático. Mas muitas análises ainda mantêm à margem essa dimensão do problema comunicacional. Obras recentes de grande circulação exemplificam de certo modo isso ${ }^{8}$. Os acontecimentos políticos acabam sempre sendo entendidos como produtos das ações de pessoas e de grupos ou de alguma força econômica ou sociológica, e o sistema midiático, que poderia ser visto como uma força econômica de grande porte, é tido como um serviçal de forças econômicas, como subalterno a elas. $\mathrm{O}$ que se propala frequentemente são entendimentos como, por exemplo, o de que as Organizações Globo estariam a serviço dessas outras forças econômicas, inclusive internacionais.

O ponto, contudo, é que os fluxos de informação que configuram a comunicação social hoje, caracterizando um espaço comunicativo, são fenômenos

8. Ver, entre outras, A democracia impedida, do cientista político Wanderley Guilherme dos Santos (Editora FGV, 2017), e Os descaminhos da esquerda, do filósofo Ruy Fausto (Companhia das Letras, 2017). A despeito das interpretações relevantes feitas ainda no calor dos desdobramentos da crise política brasileira que não arrefece, o sistema midiático tem aí papel coadjuvante. Eles o criticam, sem dúvida. Mas ainda assim seu lugar nas interpretações é secundário. Diferentemente do que se registra no recente título A Radiografia do Golpe. Entenda como e porque você foi enganado, de Jessé Souza (2016), em que o sociólogo se dedica a descrever o papel da mídia, por exemplo, federalizando as Manifestações de 2013. 
sociais e políticos de suma importância e constitutivos dos contextos formadores. E, como contextos, não só não são externos à vida política, como são sua condição.

Em todo caso, a despeito de o liberalismo clássico parecer acertar ao incluir o sistema midiático no cerne da vida política, suas disposições ideológicas atualizadas não nos oferecem instrumentos para avaliar criticamente essa posição. Tampouco rotular o sistema midiático como um inevitável produtor de ideologia pró-capitalista fora da política explica o fenômeno. Nos parece que nas sociedades contemporâneas, com sua escala e complexidade, não faz mais sentido pensar o sistema midiático nas chaves da visão instrumental de que esse sistema está a serviço de um capitalismo sem sociedade, e nem com a ingenuidade que o vê como anteposto ao poder do Estado, à moda liberal. Argumenta-se, aqui, em favor da superação dessa limitação de posições, examinando a lógica da estruturação dos sistemas nas sociedades contemporâneas. As elaborações teóricas de Habermas (1981) a esse respeito nos parecem um bom ponto de partida.

Assim, a noção de sistema assumida aqui, estribada no quadro acima apresentado, tira proveito das teorias crítica das sociedades contemporâneas que têm como fundamento a percepção de que as sociedades estão polarizadas e tensionadas entre duas dimensões estruturais que coexistem e também se opõem - o mundo da vida e os sistemas. No caso, mundo da vida e sistemas são ordens do reconhecimento social e das operações sociais diversas. Conforme Ferry (1991), tendo em vista o mundo da vida ${ }^{9}$, destacam-se as semânticas que orientam as interações sociais, cujo conjunto forma o contexto dos processos de interpretação elaborados entre os membros de uma comunidade discursiva. Elaborações vinculadas a uma razão comunicativa. Por outro lado, privilegiando-se o ponto de vista do sistema, se dá relevo ao aspecto organizacional e funcional da ação de instituições e empresas servindo à reprodução material e cultural, à reprodução global das sociedades, a partir de mídiuns que coordenam as ações (moeda, sistema monetário, segmento do sistema econômico; direito, sistema jurídico e parajurídico, que cuidaria da justiça, dos bens jurídicos sociais e individuais; democrático, sistema que organiza a representação via eleições, por exemplo). Embora no mundo da vida se produza uma vida cultural gerada nas interações subjetivas mais imediatas, as sociedades contemporâneas organizam seus sistemas culturais: a instrução é assumida por um sistema pedagógico, que por sua vez vincula-se parcialmente ao sistema científico de pesquisa, ao mesmo tempo em que a difusão de representações, mas também aquilo que pertence à função da publicidade política torna-se negócio do sistema midiático que estamos aqui

9. Mundo da vida: reelaboração importante de E. Husserl (1936), recuperada e atualizada por Habermas (1981) que o pressupõe na ordem social. 
tematizando. No caso desses sistemas culturais, substitui-se a intersubjetividade do mundo da vida por relações entre sujeitos e objetos:

\begin{abstract}
Entretanto, o mundo da vida não é mais, em nossas sociedades modernas, o único meio de reconhecimento dos indivíduos. Esses interagem socialmente sob reguladores que são mais e mais artificiais, enquanto a coordenação de suas ações recíprocas é cada vez menos realizada com a ajuda das tradições veiculadas no meio dominado pela linguagem natural. No mundo moderno, os indivíduos devem constantemente mudar de registro em razão da divisão funcional das atividades; eles lidam constantemente com o sistema como sendo outra realidade. Desse ponto de vista, pode-se, então, definir o sistema como a aparência imediata da realidade dura com a qual os atores sociais se deparam, quando eles intervêm sob os registros performantes das atividades racionais coordenadas para além da atividade linguageira natural. (FERRY, 1991, p. 18, tradução nossa)
\end{abstract}

Habermas (1981) identifica tensões entre sistema e mundo da vida que nos parecem muito produtivas para descrever nossos tempos, considera que os sistemas colonizam e oprimem o mundo da vida, cenário das relações intersubjetivas ${ }^{10}$. A assertiva é a seguinte: os processos de transferência de ações antes coordenadas no mundo da vida para o mundo dos sistemas parecem ir bem quando se trata de reprodução material, em especial nos casos nos quais essa reprodução dispensa a forma comunicativa e podem ser funcionais sob uma racionalidade instrumental, mas, quando os imperativos sistêmicos passam a dominar dimensões da vida em que são inadequados (reprodução cultural, processo de socialização entre sujeitos), as repercussões fazem precipitar as grandes questões das sociedades contemporâneas. Embora essa dominância sabote o potencial de emancipação das sociedades e de seus indivíduos, os sistemas não extinguem o mundo da vida e nem têm o condão de ser uma totalidade de produção cultural e crítica. Na tensão entre sistemas e mundo da vida permanecem conflitando a racionalidade organizacional do sistema e a racionalidade comunicacional do mundo da vida - que restitui ao ator social a capacidade de responder sobre suas próprias ações, em alguma medida.

E de que modo essa tensão entre sistemas e mundo da vida opera na vida democrática das sociedades contemporâneas de massas? Aqui é importante notar que as sociedades modernas operacionalizaram um dos segmentos fundamentais da sua vida política numa organização burocrática e jurídica constitutiva de um sistema político democrático. Isso quer dizer que o mundo da vida perde a primazia de outrora, e a formação de uma vontade política que corresponda à soberania popular

10. Entendimento que percorre a obra de Jürgen Habermas, referido principalmente na Teoria do Agir Comunicativo. Ver especialmente o capítulo VI: Segunda consideração intermediária: mundo da vida e sistema (1981, p. 205). 
se desloca conforme o funcionamento de um sistema estruturado, que opera com racionalidade e lógica próprias.

Por princípio, a democracia pressupõe que a sociedade aja sobre si mesma, por meio de uma vontade política que corresponda à soberania popular. A produção dessa correspondência é complexa e conta, como assinalado, com a "intermediação ativa" de um sistema, na verdade de mais de um sistema ${ }^{11}$. Mesmo que a denominada modernidade da qual deriva a contemporaneidade se estabeleça historicamente numa aderência à democracia como horizonte, com o advento das sociedades de massas, a vida democrática, com esses ingredientes sistêmicos, entra em crise. Grande parte da ciência política (das ciências sociais em geral) praticada no âmbito acadêmico percebe essa crise, mesmo quando não põe como cerne essa relação sistemas/mundo da vida.

A crise que é estrutural, concentra-se no fato de que a "vontade política" que se manifesta nos mecanismos cada vez mais fechados e inacessíveis do sistema político (processos eleitorais, formas de representação, produção da legislação, etc.) padece por ter escassa legitimidade, pois há dificuldades de "canalizá-la" para o interior do sistema político. Ela é constituída por fluxos aleatórios, esporádicos, plurais e desorganizados de comunicação intersubjetiva no seio do mundo da vida. (FERRY, 1991). Essas manifestações não se organizam e nem são "requisitadas" pelo sistema democrático.

$\mathrm{Na}$ realidade, o sujeito coletivo da vontade política numa sociedade contemporânea não poderia retornar ao solo original das práticas consensuais no mundo da vida. Nossas sociedades têm uma escala e uma complexidade que torna isso muito improvável. Mas isso não quer dizer que na formação da vontade política (que é parte na busca da expressão da soberania popular) o mundo da vida seja rifado. A relação com o mundo da vida que se dá de forma efêmera e que é orientada por uma razão estratégica e instrumental é, possivelmente, uma das traduções da crise das democracias contemporâneas. A vontade política formal produzida no interior do sistema democrático é medida pelos resultados numéricos dos escrutínios eleitorais gerais e parciais. Pela relação instrumental com o mundo da vida, essa vontade política reduz-se a uma soma aritmética de vontades individuais isoladas. Um arremedo de vontade política democrática, portanto.

11. Grande parte das discussões sobre modelos de democracia política, regimes de governo, mecanismos de representação ou então de formas mais diretas de formação da vontade política são, na verdade, debates em torno de como organizar o sistema político, sobre como organizar um sistema em si, como torná-lo mais eficiente. A perspectiva de uma relação mais equilibrada desse sistema com o mundo da vida já não conta com as mesmas atenções. 
Nessa interpretação, fazendo justiça à vida política e democrática completa, é necessário que tratemos, além da questão da formação da vontade política, do outro componente da vida política, também produzido no âmbito de um sistema, que é a opinião pública. Conceitualmente, no mundo da vida a intersubjetividade já conteria em si o germe dessa opinião pública. Nas sociedades contemporâneas de massas, a realidade da opinião pública na qual uma população genérica expressa, de modo difuso e cotidiano, muito mais que sua vontade política, pode ser caracterizada a partir da tensão estabelecida entre sistemas e mundo da vida. Ela também se produz, provavelmente, numa relação instrumental de um sistema com o mundo da vida e tende a ser assimilada aos resultados estatísticos produzidos pelos institutos de sondagem, que nada mais são do que agregados estatísticos de opiniões pautadas por esses mesmos institutos: ora, o sistema que produz, seleciona e difunde informações e opiniões, inclusive as políticas, e que depois procura colher o que elas suscitam em termos de respostas como sendo a opinião pública, é o sistema midiático, protagonista da comunicação social nas sociedades contemporâneas de massas.

A conjuntura cujos lineamentos são essa opinião pública formada nessas condições é o espaço onde as forças e as instituições pertencentes ao sistema político tout court atuam, disputando, por sua vez, a vontade política objetiva no momento eleitoral. Essas situações podem se confundir, pois não tem sido incomum, inclusive no Brasil, que as sondagens da opinião pública adquiram o mesmo status e a mesma função da vontade política eleitoral ${ }^{12}$.

Nos termos descritos, tanto a vontade política quanto a opinião pública permanecem largamente desconhecidas e exteriores ao sistema democrático strictu sensu, já que o que move o sistema político e a opinião pública são quase simulações, tamanho é o grau de condicionamento das lógicas sistêmicas. Essa frágil legitimidade do sistema político e da produção de uma opinião pública não consegue ser compensada apenas com a legalidade dos procedimentos democráticos dos próprios sistemas, falta-lhes alguma forma de relação com o mundo da vida, que não impeça o fluir de alguma intersubjetividade na formação da vontade política

12.Afinal, não é por conta dos resultados estatísticos das sondagens de opinião pública que muitos defenderam a legitimidade democrática do impeachment de Dilma Roussef? O sistema político eleitoral dá acesso ao cargo, e as sondagens podem revogá-lo. Para uma reflexão mais detida, ver Mídia, misoginia e golpe, organizado por Laboratório de Políticas de Comunicação-LaPCom, do Programa de Pós-graduação da Faculdade de Comunicação da Universidade de Brasília -FAC/ UnB, e do Grupo de Trabalho Políticas e Estratégias de Comunicação da Intercom - Sociedade Brasileira de Estudos Interdisciplinares da Comunicação, FAC livros, UnB, 2016, disponível em https://faclivros.files.wordpress.com/2017/03/faclivros_midiamisoginiagolpe.pdf . Acesso em: 10 mar. 2018. 
e da opinião pública. Nesse ponto, talvez seja preciso notar que essa mudança democrática na relação sistemas/mundo da vida, não se confunda com a ideia de uma necessária transparência do sistema político, dos políticos. Em recente ensaio, o filósofo Byung-Chul Han argumenta que o clamor por transparência não é uma reivindicação política, tampouco democrática:

o imperativo da transparência serve sobretudo para desnudar os políticos, para desmascarálos, para convertê-los em objeto de escândalo. A reivindicação de transparência pressupõe a posição de um espectador que se escandaliza. Não é a reivindicação de um cidadão com iniciativa, mas a de um espectador passivo. A participação tem lugar na forma de uma reclamação ou de uma queixa. A sociedade da transparência, que está povoada de espectadores e consumidores, funda uma democracia de espectadores. (HAN, 2014, p. 14, tradução nossa).

\section{O SISTEMA MIDIÁTICO E A VIDA POLÍTICA}

Nos parece, diante do exposto, que não há como negar que a vida política numa democracia contemporânea de massas se organiza em dois sistemas interligados, responsáveis pela expressão da vontade política e da opinião pública, os quais, combinados, corresponderiam à manifestação da soberania popular que autoproduz seu mundo social. No caso, como parte inerente (interna, constituinte) da vida política, o sistema midiático se relaciona, como já ressaltado, à opinião pública, cuja referência é a "nobre" função de publicidade. E a questão que se põe, então, é: como é essa relação? Mais precisamente: o sistema midiático se mantém nos limites dessa relação? Mais além: qual a sua participação efetiva na vida política?

Vinculando essas interrogações às questões da legitimidade duvidosa dos sistemas na vida política, vale ressaltar uma surpreendente situação. $O$ sistema político formal sustentado no mecanismo da representatividade encontra dificuldades, quase que insuperáveis, para retornar com alguma frequência à opinião pública onde foi obtida e formada a vontade política. Essa é mais uma razão do déficit de legitimidade do sistema político formal. Do outro lado, o sistema de produção da opinião pública, embora também suscite questões de legitimidade nosso ponto central aqui -, não o faz pelas mesmas razões que afetam o sistema político. A dificuldade de se relacionar com a opinião pública no exercício do poder ou do mandato não se coloca para o sistema midiático.

A princípio, o sistema midiático tem uma condição relacional a seu serviço pela difusão e constância de suas mensagens direcionadas ao público. E também pode obter com frequência respostas orientadoras de sua ação, via sondagens que ele pode encomendar a empresas que, em geral, são matrizes de sociabilidade do próprio sistema. Isso lhe dá mais poder e permite se autoatribuir uma condição de 
legitimidade e de representatividade da opinião pública superior às possibilidades do sistema político.

Os desdobramentos dessa caracterização são muito interessantes tendo em vista a crise brasileira. Uma opinião mais ou menos cristalizada por parte das esquerdas e dos democratas autênticos é a de que a mídia tem feito campanha desqualificante contra a política, mas seria mais preciso indicar que se trata de uma atuação contra o sistema político formal e nessa ação o sistema midiático amplia seu poder no complexo político por sua condição de simular maior legitimidade junto à opinião pública. Essa supremacia do sistema midiático na vida política é, talvez, a face mais evidente do perfil das democracias nas sociedades contemporâneas.

Há ainda vários aspectos a se abordar para se responder às interrogações postas. Os mídiuns constitutivos do sistema midiático, que são os mais dominantes na formação da opinião pública, portanto elemento essencial na manifestação da soberania popular, têm, em geral, autonomia organizacional em relação ao Estado. Isso seria democrático? Pela visão do liberalismo clássico, totalmente. Os mecanismos que formam e transmitem a "vontade geral" para o corpo social não devem se limitar mais à mediação de um aparelho estatal, nem apenas à representação parlamentar, mas supõem também uma série de agências visando capturar e traduzir as diversas correntes ideológicas para convertê-las em forças políticas. $\mathrm{O}$ potencial de expressar cotidianamente a pluralidade presente na opinião pública aumenta o poder político do sistema midiático nas democracias modernas, pois isso reforça, a princípio, sua legitimidade virtual.

Ele é o único que tem potencial de fazer as sociedades se autorrepresentarem, graças à publicidade que ele pode permitir e às diversas manifestações da vida social e da vida política propriamente, que são dadas em narrativa em gêneros discursivos diversos. Daí que os atores do sistema midiático procurem se legitimar como os porta-vozes da opinião pública, afim de consagrarem seu mídium como o único capaz de assegurar a verdadeira publicidade. Uma prática que configura um dado interessante para nossa análise, pois essa posição reivindica sub-repticiamente o monopólio da representação da pluralidade, o que supõe não haver problema no monopólio dos meios, o que, então, se estabelece como um pré-construído jamais problematizado.

Mas se abstraímos, nesta altura, as questões de legitimidade existentes nas relações atuais do sistema midiático em relação ao mundo da vida, ainda explorando o potencial positivo que de sua participação na vida política, há que se admitir, no que tange à formação da opinião pública, que o sistema midiático é o ambiente de integração da vida política. Com seu alcance informacional, pode operar uma 
integração social, política, cultural e territorial ${ }^{13}$. Nesse sentido é que ele funciona como um equivalente dos sistemas pedagógicos exoeducativos que participam da criação do sentimento de pertença nos processos de integração dos Estados-nação modernos (GELLNER, 2001). Na verdade, esse potencial vai além daquele do sistema pedagógico, pois sua emissão de mensagens e opiniões pode repercutir, mais difusa e não controladamente, para um público sem prévia delimitação, inclusive ultrapassando a escala nacional. Ele é um alargador de contextos geográficos. Assim, ele pode contribuir para a formação de julgamentos esclarecidos, do pensamento crítico, das identidades e personalidades descentradas, das solidariedades alargadas, logo, na integração social como fomentador da cidadania. ${ }^{14}$ Tudo isso sendo honrado, seria parte da legitimação do sistema midiático numa sociedade democrática. Em síntese: o sistema midiático é a forma organizada que a comunicação social, para muito além da interlocução característica do mundo da vida, assume.

\section{AS QUESTÕES DE LEGITIMIDADE DO SISTEMA MIDIÁTICO}

Delimitadas a inserção do sistema midiático no complexo sociopolítico e descritas suas relações com a vida política, voltamos ao ponto crucial destas reflexões: o mal-estar da comunicação que consiste na violação da opinião pública pelo sistema midiático. O que supõe, segundo o que foi apresentado, pensar sobre a legitimidade autoconstituída desse sistema e a impossibilidade da constituição de cidadãos alheios a esse sistema.

13.As organizações Globo fizeram isso durante o regime militar instaurado em 1964 e muitos dizem que instrumentalizadas pelos próprios militares e, se assim foi, pode-se dizer, na atual conjuntura, que a criatura acabou dominando o criador. Muito esclarecedor é o artigo intitulado "Julgamento da Revolução", assinado pelo jornalista Roberto Marinho e publicado em outubro de 1984 no jornal O Globo. Disponível em http://www.robertomarinho.com.br/vida/opiniao/brasil/julgamentoda-revolucao.htm. Acesso em: 10 mar. 2018.

14. Na ideologia democrática, toda comunidade política implica num reconhecimento recíproco entre seus membros, o que é um fato que constitui a própria comunidade política. É uma igualdade desse tipo que a cidadania exige: não uma igualdade de condições, mas uma igualdade de disposições. Enquanto cidadãos, os co-societários não são designados pelos predicados individuais: eles se autoinstituem pela relação que eles declaram entre eles. Assim, a cidadania libera as pessoas dos seus contextos empíricos. À política convém, com efeito, por essa abstração, afirmar o valor absoluto do indivíduo. Por sua vez, aquele que vive em harmonia com suas tradições, com sua cultura, com sua rede de convivialidade e nas paisagens familiares de uma vizinhança tranquila, terá poucas incitações para desenraizar a identidade natural que se desenvolveu no seu ambiente imediato. Inversamente, os homens e as mulheres da rebeldia são os primeiros candidatos à cidadania. Eles são os primeiros politizados. Nenhum outro pertencimento conta para eles, a não ser aquele de uma comunidade política que, mesmo sem ignorar as diferenças de sexo, de classe, de cultura, e também de competência, de qualificação, de produtividade, não faz de nada disso critério para a cidadania. E, sim, o reconhecimento. (Cf. FERRY, 1991) 
O grande nó que afeta a legitimidade do sistema midiático encontra-se no fato de que, na relação desse sistema com o mundo da vida, produz-se uma comunicação que é movida e orientada por uma razão instrumental, por dispositivos que configuram vetores de sensibilidade (meios técnicos e canais de veiculação) que suprimem em grande medida a intersubjetividade, o que é uma contradição profunda. Sem sujeitos em interação podemos nos referir a algo que mereça ser chamado comunicação? Como diz Niklas Luhmann (em FERRY, 1991), trata-se da ilusão de uma comunicação sem atores, de uma comunicação que comunica ela mesma, utilizando os registros diferentes da estratégia (dos meios de produção e difusão) e da dramaturgia (dos discursos textualizados). Do interior do sistema midiático, jornalistas, líderes políticos e líderes intelectuais dirigem-se ao público como um alvo, como um objeto. Daí o esvaziamento da noção de comunicação que está na raiz das questões de legitimidade do sistema midiático.

Outra questão pouco tematizada que está implicada na legitimidade do sistema midiático diz respeito à liberdade de imprensa, que se realiza pela liberdade de opinião e de expressão. A liberdade de imprensa tal como está concebida é uma face importante do mal-estar na comunicação. A sensibilidade liberal trata esse tema como um eulogismo ${ }^{15}$ intocável, o que o deixa distante do questionamento crítico, com efeitos nefastos para a vida democrática. Afinal, o que é a liberdade de imprensa? É uma liberdade negativa, isto é, uma liberdade privada. Exigir que haja pluralismo ideológico e cultural num veículo da mídia é ferir, logicamente, esse tipo de liberdade, pois essa liberdade é vista como uma prerrogativa da empresa. Ela reivindica a liberdade para emitir um posicionamento, e a exigência do pluralismo é constrangedora. Portanto, dessa liberdade negativa nada pode ser exigido, pois essa seria sua condição de liberdade. O jornalista, portador dessa liberdade privada, é compreendido nesse lugar como o porta-voz (o representante) da opinião pública, pois por meio de sua liberdade de expressão o público pode se manifestar. (FERRY, 1998) De fato, o "comunicador" (e não só jornalistas o são) se dirige ao público, tem a iniciativa, e o público reage ao que ele diz, o que é muito diferente de dizer que o jornalista é o representante do que o público elabora, das posições que assume.

Embora essa liberdade seja vista como intocável pelos democratas autênticos, inclusive pelos não tão liberais, a vida real é plena de casos de abusos graves produzidos por essa liberdade. Como evitá-los, sem violar essa liberdade negativa? Esse é o ponto do qual nunca se sai quando o tema é a regulação dessa liberdade. O risco, para os defensores dessa liberdade negativa e privada, seria a onipotência

15. Termo carregado de um poder encantatório, que eleva as discussões, os argumentos e as pessoas. O contrário de dislogismo, cujos efeitos são inversos. 
democrática (a vontade geral) se impor sobre a existência individual, isto é, de um direito público, coletivo, invadir os direitos do indivíduo, que é, na verdade, a grande questão do liberalismo clássico. Mas talvez agora possamos inverter esse temor, pois também é perigoso quando um direito privado, do indivíduo liberdade de expressão e de opinião - invade a esfera pública e se impõe a ela de forma abusiva. Mas, os operadores do sistema midiático admitem no máximo a autorregulação privada, isto é, reivindicam a liberdade de serem eles mesmos os seus controladores. Recusam qualquer controle externo argumentando que a autorregulação seria suficiente para evitar os abusos, por meio de uma ética do jornalismo ${ }^{16}$, que é completada pela ética do indivíduo jornalista. Trata-se, portanto, de um autocontrole moral. Se isso não bastar, entende-se, dessa perspectiva, que o público saberá rejeitar os abusos.

Mesmo sem considerar os fatos empíricos incandescentes que envolveram (e envolvem) a atuação da mídia na crise política brasileira, não há garantias convincentes que essa autorregulação prospere. São tantos os motivos, que é até difícil hierarquizá-los. Em termos de funcionamento do sistema, não há, por meio desses procedimentos de autorregulação, qualquer garantia e comprovação de que a mesma liberdade de opinião e de expressão esgrimida com valentia pelos jornalistas em relação ao público seja praticada perante os seus patrões. Logo, orientada e constrangida pelos empresários, a tão propalada liberdade de expressão chega ao público adulterada. É de se destacar também que o público, na condição dominante de objeto, podendo praticar apenas limitadamente uma recepção autônoma, não tem as condições sistêmicas (previstas nesse funcionamento) de ser o juiz supremo do abuso da liberdade de imprensa.

Apesar das evidentes fragilidades lógicas da eficiência da autorregulação, os operadores do sistema midiático e, para além deles, parte da sociedade civil democrática, veem a regulação externa (heterorregulação) como um tabu, como ameaça à democracia. No entanto, diferentemente da autorregulação, baseada na expectativa da ética jornalística e da moral do jornalista, ela se estruturaria com base em direitos, expressos em leis e regulamentos. Por exemplo: o direito de resposta

16.A ética jornalística se sustentaria na reportagem, que seria sua essência e que se constrói com base nos fatos (ver, por exemplo, Bertrand, 1999). Os procedimentos organizados a partir dessa ética pregam investigação independente, desligada de interesses de poderes oficiais e privados. $\mathrm{O}$ trabalho exige a checagem prévia, autônoma e ponderada de informações por meio do confronto com outras informações, checando e registrando versões muitas vezes contraditórias. Demanda o veto de informações suspeitas ou apressadas, extirpando especialmente as que podem estar contaminadas por viés político. O jornalismo ético se vale de fontes plurais, segue diferentes linhas de investigação, tenta construir um retrato dos acontecimentos e desconfiaria sempre dos poderosos. 
e regras para cumprir algum tipo de pluralismo na concorrência, na programação e nas identidades ideológicas. Assim, uma heterorregulação que estabeleça para a comunicação na imprensa alguns parâmetros definidos democraticamente no sistema político ganharia status de direito público, e deixaria, nesse sentido, de ser algo privado.

Mas esse raciocínio não abala os patronos da liberdade de expressão e de opinião privada como fonte do exercício da liberdade de imprensa. A defesa da autorregulação se dá por motivos negativos, afinal a história da imprensa oferece elementos em abundância para apoiar esse temor, e como todos sabemos a luta pela liberdade jamais está totalmente ganha. (FERRY, 1998) Especialmente se a imprensa, via esse recurso da liberdade de expressão e opinião, deixar de ser o espaço de defesa da população contra os poderes constituídos, em especial, contra o poder do Estado. Como liberdade negativa, ela é defendida defensivamente... Defende-se a autorregulação em razão da ameaça que a heterorregulação representaria, porque essa significaria a concessão de mais poder ao Estado.

Jean-Marc Ferry (1998) propõe um teste aos defensores da autorregulação: não haveria uma argumentação positiva para justificar a autorregulação? Não haveria algo que justificasse a autorregulação pela sua competência em debelar os abusos e pela capacidade que ela teria de produzir informações de qualidade de todos os tipos? $\mathrm{O}$ mesmo Ferry ressalta algo que é importantíssimo: os conteúdos regulados apenas pelos critérios morais da autorregulação não tocam nas questões da programação dos meios audiovisuais, tampouco nas questões da tematização, afinal quem escolhe o que será objeto de informação e opinião no sistema midiático? A questão da tematização é o grande ponto cego do problema.

Entendemos que essa linha de argumentação pode tirar a discussão do impasse sobre como eliminar abusos sem ferir a liberdade de imprensa. As questões aqui levantadas são de interesse público e pertinentes à condição do sistema midiático como parte da vida política por conta de seu papel na formação da opinião pública. Recuperando uma notável percepção de Ferry (1998, p. 56): a ambiguidade da atuação desse sistema está no paradoxo de que ele opera numa dimensão pública da vida política empregando uma liberdade privada, que o sistema não prevê controlada em nenhuma medida pelo mundo da vida. Uma liberdade privada e uma autorregulação dão conta das expectativas públicas, legítimas, que se têm sobre o sistema midiático? Afinal, se o que o sistema midiático emite é material para a formação da opinião pública é porque há expectativas pressupostas ligadas à verdade, há uma boa fé de partida por parte da recepção. São expectativas públicas, que devem ser honradas. 
Como contraponto a esse impasse sobre como controlar o abuso sem incomodar a liberdade de imprensa, talvez se pudesse trocar a liberdade privada da imprensa pela liberdade pública de comunicação. Como? A resposta propõe um retorno à questão da tematização.

A formação democrática da opinião pública aconselha que os cidadãos devem ter acesso a informações consistentes de interesse público e que eles também tenham acesso a visões diversificadas, conflitantes. Desse modo, o espaço midiatizado poderia ser um campo de autorreflexão da sociedade. Mas quem define e como se definem os problemas relevantes? Dos milhões de acontecimentos diários, dos incessantes e distintos processos sociais e naturais em andamento nas diversas escalas que o sistema midiático seleciona, todos foram tematizados por critérios próprios, de forma privada e não pública. Logo, na forma de seleção dos temas, o teor público já não se apresenta nos aspectos procedimentais. Daí para frente, o campo está minado e não se pode falar legitimamente em interesses públicos. Exemplos não faltam, vamos a um bem singelo, porém grave: há hoje, no Brasil, um processo de fantasmagorização dos que discordam da voz única na mídia sobre questões econômicas; ao público brasileiro não é dado saber que as posições denominadas neoliberais em economia não são unânimes e são bastante contestadas nas universidades nacionais e internacionais e em outros países. Isso fere o interesse público.

A liberdade de comunicação teria que ser, como solução para os impasses da liberdade de imprensa privada, uma liberdade pública. Uma liberdade positiva para os cidadãos, de modo que eles mesmos pudessem contribuir para a agenda das tematizações públicas. Significa, portanto, uma maior abertura da tematização para a sociedade. Na prática, isso significa que o público teria que poder participar ao menos indiretamente da seleção dos conteúdos e dos temas midiáticos levados à sua atenção. Isso supõe que a cidadania deveria estar representada em instâncias que fariam avaliações críticas sobre a programação e participariam da produção de parâmetros para a seleção do que deve ser tematizado. Essa liberdade pública de comunicação funda um direito à comunicação que é requisito fundamental para estruturar uma democracia deliberativa ao restabelecer alguma condição de sujeito ao público ${ }^{17}$.

Ocorre que o modelo de relações previsto no atual sistema midiático em relação ao público está tão assentado, que pensar alternativamente, nos termos

17.Aqui, a história da criação da Empresa Brasileira de Comunicação - EBC, a recente dissolução de seu Conselho Curador e a decorrente mudança na produção de sua grade de programação são dados emblemáticos. Ver, por exemplo a Moção de Repúdio contra a Medida Provisória 744. Disponível em: http://www.ebc.com.br/institucional/conselho-curador/noticias/2016/09/mocaode-repudio-contra-medida-provisoria-que-desmonta-a-ebc . Acesso em: 10 mar. 2018. 
sugeridos de um direito à comunicação, parece algo contraintuitivo. Mas essa intuição pode se inverter se tivermos em conta que não podemos ter uma liberdade de expressão garantida, sem que a sociedade tenha a possibilidade de tematizar o que quer, possibilidade que está confiscada por alguns apenas, os que controlam o sistema midiático.

Por essa razão, não se deve mais, ao se pensar na liberdade pública de comunicação, perguntar em primeiro lugar se o jornalista pode falar livremente, mas, sim, se o espaço midiático é amplamente aberto às questões de interesse público, se essas questões são publicamente acessíveis e qual o grau de diversificação da tematização. (FERRY, 1998, p. 58) A liberdade de comunicação só pode ser aumentada pela via do pluralismo, e isso convergiria para uma inclinação natural do sistema midiático, caso ele mantivesse uma relação democrática com o público. Nesse caso, liberdade de comunicação e pluralismo convergem e não jogam numa razão inversa. $O$ problema novo é que se trata menos de proteger a liberdade da imprensa contra a tutela do Estado do que promover uma autonomia (leia-se formas de acesso, materiais e instrucionais) dos cidadãos face ao poder do sistema midiático.

Diante disso, enquanto a liberdade de comunicação não é conquistada, podese dizer que o sistema midiático está mergulhado integralmente na ilegitimidade e que, portanto, estamos reféns de um sistema manipulador? Talvez, mas não integralmente, pois numa situação mais ou menos democrática o sistema midiático sofre algum tipo de "domesticação". Esse, certamente, não é o caso do Brasil.

$\mathrm{O}$ que pode controlar e conferir alguma legitimidade ao sistema midiático seria certo equilíbrio pluralista, que em todas as situações é sempre muito instável, e é em torno dessa luta pelo equilíbrio que se hasteia a bandeira da democratização da mídia. Isso não supera o problema maior que é a condição de objeto do público, mas atenua essa condição com uma oferta de opções, e as mídias digitais têm figurado como possibilidades ${ }^{18}$.

De outro lado, algo que ameniza o risco de manipulação total por parte do sistema midiático é o fato de a recepção social não ser alvo de organização do sistema midiático. De alguma forma, sobrevivem nesse âmbito alguns recursos de identidade

18. Embora não possamos evitar de notar que alternativas importantes às coerções do sistema, como Mídia Ninja ("jornalismo de guerrilha" produzido por quaisquer interessados em documentar fatos no calor dos acontecimentos portando dispositivos tecnológicos básicos) ou como o blog Conversa Afiada (jornalismo baseado no capital simbólico de um ator do sistema que reivindica mudanças estruturais a partir do lugar de um detrator que conhece o funcionamento da grande mídia) estejam francamente dependentes de mídiuns como o Facebook, uma grande corporação de distribuição de conteúdos gerida no mais estrito jogo capitalista da informação como mercadoria. 
próprios ao mundo da vida ${ }^{19}$. Além disso, é tentador atribuir às redes sociais que se estruturam no ciberespaço um novo poder da recepção perante o sistema midiático. Seriam esses meios e suas redes uma ágora digital que pode conferir condição de sujeito à opinião pública? Não é o que pensam vários estudiosos dessa questão, entre os quais o já citado filósofo coreano Byung-Chul Han(2014), para quem o ciberespaço está mais para panóptico digital do que ágora.

\section{INTERPRETAÇÕES SOBRE O PROTAGONISMO DO SISTEMA MIDIÁTICO NA CRISE BRASILEIRA: A VIOLAÇÃO DA OPINIÃO PÚBLICA}

Problematizadas as tensões na relação sistema midiático/mundo da vida no fluxo da formação da opinião pública, com tudo que isso significa em termos de manifestação da soberania popular, nos parece produtivo e necessário experimentar algumas interpretações sobre a atuação e a participação do sistema midiático brasileiro na crise política que se acirra a partir de 2014 .

Comecemos com uma constatação linguística: as mudanças estruturais no quadro político, especificamente na estrutura do poder e no marco constitucional têm sido, desde então, caracterizadas por muitos críticos como um golpe de Estado jurídico-midiático ${ }^{20}$. A existência dessa posição é um exemplo chocante do malestar estabelecido nas relações do sistema midiático com o público. Não se trata de uma minoria descontente, inconformada por ter vivenciado uma derrota política qualquer, trivial num sistema democrático. Trata-se de um segmento populacional expressivo e com qualificações no âmbito intelectual, que se exaspera com as violações de teor antidemocrático que estão ocorrendo. Nesta altura, o sistema midiático o ignora. Talvez para fantasmagorizar essa crítica, o que é revelador de uma certa covardia reinante no sistema midiático ao não contestar diretamente o estigma demolidor que lhe foi impingido e que não será mais removido a não ser por imposição ditatorial. A restauração de alguma credibilidade perante esse segmento

19. É crescente a movimentação em torno das chamadas fakenews de que decorre, entre outras, a reflexão sobre uma descrença generalizada do público em relação ao que se lhe oferece como fato. Sobre isso, ver entrevista recente do linguista Noam Chomsky no Boletim Carta Maior, disponível em https://www.cartamaior.com.br/?/Editoria/Politica/Noam-Chomsky-As-pessoas-ja-nao-acreditamnos-fatos-/4/39564. Acesso em: 12 mar. 2018.

20. Sobre o atual uso do termo "golpe" para referir um acontecimento político sobre o qual há forte disputa pela atribuição de sentidos, ver artigo do linguista Sírio Possenti intitulado "Diferenças condensadas em palavras", disponível em http://periodicos.letras.ufmg.br/index.php/relin/article/ download/10959/pdf. Acesso em: 10 mar. 2018. 
expressivo da sociedade (que é crescente) ${ }^{21}$ não parece mais plausível, o que, tendo em vista a função que o sistema midiático ocupa na vida política, será um fator de permanência da instabilidade política na sociedade. $\mathrm{O}$ fato de não surgir no interior do sistema midiático nenhum laivo de autocrítica é decerto um sintoma do perfil antidemocrático desse sistema.

\subsection{0 acirramento do mal-estar}

Considerando a atuação saliente do sistema midiático na crise política, seria interessante testar se esse sistema tem honrado as expectativas de boa-fé que a sociedade nutre em relação a ele, e se o sistema tem sido fiel aos princípios que os seus próprios protagonistas, em defesa de sua liberdade, costumam apregoar. Vamos mencionar alguns fatos irrecusáveis e interpretá-los à luz das ideologias liberais e daquelas geradas pelo próprio sistema midiático, conforme a perspectiva acima detalhada.

Não vamos listar exemplos (seriam centenas) do que se pode referir por jornalismo partidário, difamatório, interessado... Caberá, em outra ocasião, examinar os enunciados em que figuram os semas fundamentais desse descarrilamento do sistema. Mas observar algumas posturas mais gerais permitirá constatar que estamos diante de uma violação na função democrática de formação da opinião pública, que justificaria a existência do sistema midiático, como vimos. Assim, consideremos:

i) A associação com órgãos do Estado brasileiro na produção de informações públicas da denominada "Operação Lava-Jato": se fosse necessário provar que essa associação existe, bastaria usar uma analogia retirada da sentença do desembargador Gebran do TRF-4 e sua lógica $^{22}$ : se o juiz Moro, que é o "autorizador" das operações da referida operação, nada fez para combater os vazamentos de informações sigilosas do sistema jurídico no âmbito dessa operação para o sistema midiático, vindas das delações, então ele

21.A esse respeito, é notável a sucessão de disciplinas e cursos de extensão que passaram a ser oferecidos em diferentes universidades públicas desde que o Ministério da Educação, com retumbante repercussão midiática, acusou de improbidade administrativa professores da UnB pela criação da disciplina "O golpe de 2016 e o futuro da democracia no Brasil". Ver, por exemplo, notícia do jornal O Globo de fevereiro de 2018, intitulada "MEC vai acionar MPF contra disciplina da UnB sobre 'golpe de 2016". Disponível em https://oglobo.globo.com/brasil/mec-vai-acionar-mpf-contradisciplina-da-unb-sobre-golpe-de-2016-22420187\#ixzz59TjTBE00. Acesso em: 10 mar. 2018. Sublinhe-se que as aspas no termo "golpe de 2016 " mostram o distanciamento que o locutor toma dessa designação, e que a cadeia de retomadas produzida em outras universidades, não tematizada na chamada grande mídia, tem como característica justamente retomar ipsis litteris o nome da disciplina "original".

22. Esse desembargador usou essa lógica no seu relatório que abriu o julgamento dos recursos interpostos pela defesa de Lula, no dia 24 de janeiro de 2018, no Tribunal Regional Federal -4. 
é o chefe do "vasoduto", como a crítica denominou ironicamente esse esquema. Lembremos: a ética jornalística teria como núcleo essencial a reportagem, um dos elementos garantidores da autorregulação contra abusos (ver nota 16). Segundo o depoimento do jornalista Mário Vitor Santos ${ }^{23}$, no caso da operação em tela, os "furos", informações exclusivas e inéditas, que são a razão de ser do jornalismo investigativo, não existiram, pois os meios de comunicação foram receptadores de "vazamentos", ou seja, de informações obtidas, recortadas e liberadas por três fontes, todas órgãos do Estado brasileiro: o Ministério Público, a Justiça Federal e a Polícia Federal. Assim, os agentes públicos - e os jornalistas que com eles trabalharam violaram com constância o sigilo processual e comandaram o noticiário.

Santos insiste, em seu depoimento, que o jornalismo teria sido instrumentalizado. O que seria uma corrupção do que o define, como vimos. Mas, de fato, o sistema midiático brasileiro mostrou-se muito poderoso e autônomo e fez com esses órgãos estatais uma aliança notória, de iguais. Não se percebe uma posição subordinada do sistema midiático em relação a esses órgãos, tampouco a outros do poder público que poderiam impor sanções a esse funcionamento. Havia, desde as chamadas Manifestações de 2013, tal sincronia das notícias com eventos e com o aumento da temperatura política do país rumando em direção ao impeacbment de Dilma Roussef, que essa relação e a oportunidade dos vazamentos indiciam tal aliança. A "informação explosiva" vazada não era apresentada de forma improvisada, muito ao contrário, o que mostrava que a tal força-tarefa da operação em curso se completava nessa associação do Estado com o sistema midiático. O que resultou foi que o espaço midiático, aquele com potencial de se transformar num espaço público de formação democrática da opinião pública, transmutou-se numa instância de julgamento e "linchamento" (GENRO, 2017, p. 449) ${ }^{24}$. Nessa praça soterrou-se um princípio constitucional da presunção de inocência, aliás, um direito individual que é irmão da liberdade de expressão e opinião, considerados direitos correlatos. Nesse caso, a condenação prévia dos ilegalmente acusados nessa ágora desvairada resultou da desonra a que a liberdade de imprensa foi submetida pelo próprio sistema midiático.

23. Ex-ombudsman do jornal Folha de S. Paulo, figura simbólica da autorregulação da imprensa. É bom lembrar que o descarrilamento desse jornal em relação ao público que lhe conferiu status de liberal-democrático se deu com a presença dessa crítica interna que o ombudsman representaria. O jornalismo barnabé e a derrubada de Dilma. Disponível em:https://www.cartacapital.com.br/ sociedade/o-jornalismo-barnabe-e-a-derrubada-de-dilma. Acesso em: 12 mar. 2018.

24. "Sequência do massacre midiático, patrocinado de forma consciente pela maioria da mídia tradicional, que foi guindada, inclusive, à condição de processante 'ex-oficio', através das suas manchetes arbitrárias" (Tarso Genro, no livro organizado por PRONER $;$ CITTADINO, RICOBOM; DORNELLES. Comentários de uma sentença anunciada, Bauru: Canal 6, 2017, p. 449) 
Os vazamentos "estrelados" por essa aliança escusa foram indireta e cinicamente defendidos como realização da nobre função da publicidade, alegandose tratar-se de informações de interesse público. Será de interesse público derrogar um dos princípios constitucionais que protegem os direitos dos indivíduos (a presunção de inocência), sem que esse mesmo público tenha assim decidido?

Essa associação ilegal é, porém, protegida pelo direito de livre expressão e pelo direito de preservar suas fontes. $O$ agente público transgride as leis vazando informações sigilosas, mas o faz protegido por uma lei que garante o seu cúmplice. Qual seria a notícia a dar segundo a deontologia jornalística, pilar da autorregulação: o conteúdo do vazamento ou que um agente público está fazendo vazamento criminoso? Ora, a liberdade expressão e a autorregulação privada não devem ser defendidas para proteger a sociedade civil contra os abusos do poder de Estado? Não é inclusive com esse argumento que se repudia o controle externo sobre o sistema midiático? Então como se justifica essa aliança estratégica com a Polícia Federal e o Ministério Público (e o juiz, que já está aliado com aqueles órgãos, o que é um outro elemento espúrio desse processo) em flagrante abuso do poder, colocando-se contra uma força política, um campo político, uma parte da população? E sem direito de defesa, num ato de linchamento, pois nesse não se dá a palavra àquele que será linchado. Desse modo, o sistema midiático compromete a sua legitimação, pois absorve parte do poder do Estado, de que deveria se distanciar justamente como mediador da sociedade, e o transforma em seu próprio instrumento de poder contra o público, numa flagrante violação deontológica, cujas armas estão sendo acumuladas ameaçadoramente para o futuro. Essa associação é um poder intimidador contra aqueles que acedem ao Estado pelo voto, pois é brandida por uma aliança, indevida do ponto de vista constitucional, de instituições que não acedem ao poder por meio de eleição.

ii) Ação política própria: ainda no referido depoimento, o jornalista Mario Vitor Santos afirmou que, no impeachment, o peso da mídia foi mais relevante que o de Eduardo Cunha, deputado federal que conduziu, no âmbito do Congresso Nacional, as manobras necessárias à configuração do impedimento de Dilma Rousseff, nas precárias condições jurídicas em que se deu. Podemos acrescentar que, após o impeacbment, o sistema midiático ampliou seu poder, afinal é isso que acontece com os generais que vencem as batalhas. E esse seu poder passou a ser exercido junto ao governo que então se instalou.

Antes do impeachment, o sistema midiático substituiu a oposição política legítima, que veio a reboque tomar o poder. Segundo Jessé Souza (2016), entre outros observadores atentos, o sistema midiático está implicado na federalização 
das Manifestações de 2013, dando uma orientação a seus desdobramentos cada vez mais contrária às motivações iniciais (relativas ao aumento da passagem de ônibus na cidade de São Paulo e, depois, em outras cidades do país), e na amplificação dos protestos em reação à Copa do Mundo de Futebol que aconteceu no Rio de Janeiro, sobre a qual se avolumou o discurso de que o Brasil não lograria garantir as condições adequadas para recepcionar evento desse porte, e também contribuiu para encorpar a sublevação contra os resultados das urnas de 2014 e sepultar o período de trégua pós-eleitoral.

Tudo isso foi muito perturbador, pois a aliança do sistema com a Operação Lava-Jato já havia se dado antes das eleições, e os vazamentos impactaram fortemente o processo eleitoral (assim como vão impactar posteriormente nos processos judiciais que seguirão). Nesse caso, esse poder político, para além de sua função política de cenário de formação da opinião pública, cresceu provavelmente além do esperado pelo próprio sistema midiático, já que a aliança com órgãos do Estado ainda estava estreando e não se podia saber os efeitos que isso produziria na formação da opinião pública. Mas logo ficou claro o poder explosivo que estava à disposição dessa aliança: o governo eleito em 2014 foi derrubado com anuência jurídica fartamente documentada pela mídia, o novo governo se instalou e o Congresso Nacional passou a implementar um conjunto de mudanças (inclusive algumas que desconstituem a Constituição de 1988, como a "PEC da Morte" e, de certo modo, a Reforma Trabalhista ${ }^{25}$ ) sob forte prescrição e pressão dessa aliança do sistema midiático e da referida força-tarefa. O poder de fogo que essa aliança tem, cujas armas principais não são as eventuais informações sobre esquemas e pessoas implicadas em corrupção, é justamente a liberdade que tem no modo de trabalhar essas informações, de retomá-las cotidianamente em paráfrases não controladas junto a um público submetido como objeto. O programa de "governo" que não foi eleito, é prescrito pelo sistema midiático, sem abertura alguma para dissenso. Os esforços para esconder as divergências são inúmeros. Eis a violação da opinião pública e da soberania popular engendrada por um sistema que a princípio tem funções na construção da democracia das sociedades contemporâneas.

É claro que a perturbação social e a inflamação de ânimos diante do linchamento diário promovido por essa aliança estabeleceram um nível de revolta

25. No dia 11 de julho de 2017 a reforma trabalhista foi aprovada, depois de tramitar aceleradamente, com o sistema midiático ditando o ritmo, no âmbito do Congresso Nacional. Está sendo contestada juridicamente, inclusive por juízes da própria Justiça do Trabalho. Seus pontos são polêmicos, podemos citar: prevalência do acordado entre as partes ao legislado; vários contratos de trabalho, onde se destaca o trabalho intermitente que pode levar um trabalhador a ser remunerado abaixo do salário mínimo. 
que pode redundar em grandes manifestações sociais. Isso por si só já seria uma violação da missão da publicidade, da formação da opinião pública. Mas sempre há mais um Rubicão a se transpor: o sistema midiático, com seus veículos e empresas em grande harmonia, num contrato mantenedor de sua condição de matrizes de sociabilidade, participou da ativamente da organização dos movimentos de rua, convocou-os, instruiu sobre como participar deles, propôs suas feições semióticas (cores, artefatos, modos de documentação e difusão dessa documentação). Sempre em combinação com novos vazamentos, traçou roteiros de cobertura e repercussão e definiu a potência dessas manifestações para a vida política do país. E nessa arena, da pressão direta sobre forças políticas instaladas no governo, o sistema midiático não tem (pela definição de seu funcionamento deontológico) legitimidade para atuar, e se o fez, foi como usurpador e violador.

Ora, o envolvimento nesses termos abusivos e ilegítimos do sistema midiático na vida política fere e trai as intuições, as expectativas que o público, com sua boa fé, tem em relação ao sistema midiático. Assim, o sistema midiático deixa de ser meio e passa a ter fins, o que obviamente é incompatível com a vida democrática, e com a própria reinvindicação de liberdade do sistema midiático.

iii) Desintegração social: relembrando que um dos elementos legitimadores do sistema midiático numa sociedade contemporânea é o potencial de integração social que ele pode exercer, não só na vida política, como também na vida social geral, torna-se inaceitável que a operação desse sistema tenha ido em direção contrária: fragmentando a sociedade. Terminada a eleição presidencial de 2014, as análises veiculadas intensamente no sistema midiático sobre os resultados eleitorais promoveram uma grande impostura intelectual e ética, por meio da produção, inclusive com muitos mapas (supostamente a documentação técnica inconteste), de uma imagem de país dividido regionalmente e socialmente. Produziu-se uma coincidência entre o regional e o social com base na desqualificação do voto popular do Nordeste, apresentando-se o Sudeste e o Sul como vítimas do clientelismo que teria grassado alhures. Isso perdurou enquanto Dilma Rousseff esteve no poder, e essa duração - eivada de repetição - é parte importante da produção de um imaginário, produz tecnicamente sua prevalência. Evidentemente, no sistema midiático tinham (e têm) voz aqueles que convergiam para o intuito pouco disfarçado. Ainda marcará época a repercussão que o sistema midiático deu a uma opinião do Ministro do Superior Tribunal Federal, Gilmar Mendes, acumulando o cargo de presidente do Tribunal Superior Eleitoral: o ministro declarou que o programa Bolsa Família era um esquema de compra de votos sem equiparação. Discursos que desqualificam e deslegitimam opções políticas com base em preconceitos sociais e regionais 
são ações que corroem os princípios da cidadania, são ações que desagregam a comunidade política e que desonram também um dos pilares legitimadores do sistema midiático.

Outra recorrente ação desagregadora da comunidade política e, portanto, da sociedade perpetrada pelo sistema midiático foi aquela de planejadamente fantasmagorizar a oposição à marcha dos acontecimentos. Não faltou cinismo nessa ação, numa postura de franco desafio e ofensa a uma parte da população: os que se opunham do curso dos eventos orquestrados rumo ao impeacbment, além de calados na cena pública, eram insultados com frequência nos editoriais dos jornais impressos e digitais, como "cúmplices da corrupção", "brasileiros não patriotas", ou até como "não brasileiros verdadeiros" ${ }^{\prime 26}$. Assim, se não são patriotas e se são cúmplices da corrupção, não teriam legitimidade para reivindicar publicidade de suas posições políticas. O não reconhecimento das posições diferentes e de seus protagonistas é uma ação desintegradora e perturbadora da ordem, de uma sociedade que se imagina democrática: é assédio, é violação da opinião pública e do critério do reconhecimento recíproco, base da cidadania. Basta lembrar uma recorrência, que é histórica e cotidiana, só que agora acirrada pela temperatura da crise política no país: o blog 247 trouxe no dia 16 de janeiro de 2018 um comentário sobre editorial do jornal O Globo em que figura esta passagem: "Em mais um editorial (...) o jornal O Globo tenta responsabilizar o PT pela segurança em Porto Alegre no dia do julgamento do ex-presidente Lula." Em seguida, a matéria do apresenta um trecho do editorial em pauta: "A convocação que o partido e organizações ditas sociais fazem para militantes estarem em Porto Alegre no dia 24 é pressão política, indevida, sobre os desembargadores do TRF-4." Eis uma posição desintegradora que pode passar desapercebida, porém deslegitima o sistema midiático como funcionamento de mídiuns destinados à formação da opinião pública democrática. O termo "ditas sociais" marca que o jornal não reconhece grupos de brasileiros que se mobilizam em torno de temas, de causas, etc. Ou, se reconhece seletivamente, ainda perde seu sentido e legitimidade, pois viola o princípio fundante da cidadania.

26. Em termos discursivos, importa esclarecer como uma semântica midiática é retomada em outras ações comunicacionais não jornalísticas propriamente, como a recente implantação de grandes mastros com bandeiras do Brasil tremulando ao longo de vias importantes, como a Av. Brasil em São Paulo, nos quais uma placa registra: "EU AMO O BRASIL". Em São Paulo, foram patrocinadas por uma parceria entre a Prefeitura Municipal e o escritório de advocacia Braga Nascimento e Zilio Advogados. Sublinhem-se a memória discursiva aí evocada - do slogan bastante conhecido "Brasil, ame-o ou deixe-o" - e o fato de se haver fundado uma Associação EAB - Eu Amo o Brasil promovendo ações desse jaez, isto é, de valor semiótico, nutrindo imaginários. (verhttp://www. euamoobrasil.org.br/noticia/avenida-brasil-e-colorida-com-bandeira-nacional). Acesso em 12 mar. 2018. 
É uma visão diminuidora do todo social, o que é diferente de discordar e até de ser adversário dos movimentos em questão. Ser adversário é um reconhecimento.

iv) A tematização fraudando o interesse público: a ausência de discussão sobre nossa vida política faz com que assumamos que, automaticamente, de uma maneira ou de outra, o sistema midiático acabe veiculando os "fatos que importam" e que são de interesse público. Mas há uma tematização que é feita pela mídia, um monopólio da agenda setting do noticiário, como já abordado anteriormente. Assim, estamos sujeitos (como objetos) à superexposição ou ao silenciamento de temas definidos sem garantia de que eles tenham interesse público. Eis a expressão da liberdade restrita de comunicação do público.

É preciso alertar que a questão da tematização centralizada, distante do interesse público, não se manifestou apenas na crise política que abordamos aqui. Ela é frequente e afeta gravemente nossa ordem social ${ }^{27}$. No entanto, a tematização interessada proliferou durante a crise política em tela. Um caso paradigmático foi a aprovação da PEC 241 ("Pec da morte"). No dia 24 de outubro de 2016, aconteceram várias manifestações em diversas capitais e cidades do país, nas quais os protestos eram contra a PEC 241, de iniciativa de um governo de escassa legitimidade (como comprovam inclusive as sucessivas pesquisas encomendadas pelo sistema midiático, ainda que pouco ventiladas por ele). Além de polêmica em seus termos, tinha tramitado em ritmo acelerado em plena crise política, possivelmente aproveitando o período anômalo, sem envolvimento da população, sem debate. E quem garante a condição de "sem debate"? O sistema midiático, a não ser que entenda por "debate" uma profusão de opiniões convergentes daqueles que defendiam tal PEC. A busca por notícias no dia seguinte (25) às manifestações nas capas dos principais jornais impressos e digitais foi frustrante. Nada se falava a respeito. Nada no Jornal Nacional, essa entidade longeva da televisão brasileira. Blackout! Uma desonra para a nobre missão da publicidade, do poder e do dever de levar a público o que acontece. Mais uma violação da opinião pública.

27. "Cidadãos" de segunda categoria são aqueles cujas ocorrências - de vida e morte - não são dignas de tematização no sistema midiático. Negros e pobres estão nessa categoria, esse é um lugar comum, mas isso não diminui a sua verdade. Há casos de chacinas recorrentes nas periferias das grandes cidades. Não há manchete, não há capa, não há reportagem com investigação, não há jornal nacional que encampe investigações. A ausência de tematização dessa barbárie é uma violação de direitos e da opinião pública, pois, sem conhecimento, a sociedade tem suas opiniões desvirtuadas e deixa de reconhecer o outro. 


\section{CONSIDERAÇÕES FINAIS}

Para concluir, talvez seja preciso uma palavra sobre termos tratado o sistema midiático de forma monolítica, quase dando a ele o status de ator único, um ser sem contradições e diversidade. Não é que não exista uma diversidade mínima, mas mesmo essa dissolveu-se no "fogo" dos acontecimentos e o sistema movido por uma mesma "racionalidade cega" reduziu-se a uma única voz. Daí que, diante desse poderoso, ameaçador e operoso assédio tenha surgido como reivindicação forte que esse sistema tenha mais diversidade, o que foi chamado de democratização da mídia, o que evidentemente é uma expressão que não dá conta das necessidades efetivas, segundo o raciocínio apresentado.

Afinal, a diversidade de proprietários não resolve a questão da tematização, da presença dos interesses públicos e nem da formação democrática de uma opinião pública. Em todo caso, mesmo sendo uma proposta modesta, até isso é recusado pelo "nosso" sistema midiático, mantendo-se contrário e não dando azo para qualquer debate a respeito. De todo modo, esse clamor pela diversificação do sistema midiático está inscrito na constituição de 1988 (artigo 220, §5) ${ }^{28}$, mas parece que não há força política que consiga regulamentá-lo. Em 2011, 23 anos após a promulgação da Constituição, o jurista Fábio Konder Comparato, mencionado anteriormente, entrou com uma ação de inconstitucionalidade por omissão no Supremo Tribunal Federal para regular os meios de comunicação conforme o artigo mencionado, que pró́be o monopólio e o oligopólio dos meios de comunicação. A ação visava cobrir essa omissão do poder legislativo. Desde 2011 ela está sendo estudada sem nenhuma manifestação pela ministra responsável, Rosa Weber. Muitos outros projetos nessa direção já foram apresentados no Congresso Nacional nessas duas décadas e nenhum jamais foi à votação.

\section{REFERÊNCIAS}

BERTRAND, C-J. (1997) A deontologia das mídias, trad. Maria Leonor Loureiro. Bauru: EDUSC, 1999.

\section{Capítulo V}

\section{Da Comunicação Social}

Art. 220. A manifestação do pensamento, a criação, a expressão e a informação, sob qualquer forma, processo ou veículo, não sofrerão qualquer restrição, observado o disposto nesta Constituição $\S 5^{\circ}$ Os meios de comunicação social não podem, direta ou indiretamente, ser objeto de monopólio ou oligopólio.(CONSTITUIÇÃO DA REPÚBLICA FEDERATIVA DO BRASIL DE 1988, acessível http://www.planalto.gov.br/ccivil_03/constituicao/constituicaocompilado.htm). Acesso em: 12 mar. 2018. 
DEBRAY, R. (1996) Transmitir, trad. Guilherme Freitas Teixeira. Petrópolis: Vozes, 2000a.

DEBRAY, R. (1999) Introduction à la médiologie. Paris: PUF, 2000b.

FERRY, J-M. (1991) Les puissances de l'experience. 2. Les ordres de la reconnaissance. Paris: Les Éditions du Cerf.

FERRY, J-M. (1998) Culture et médias dans l'espace européen. Pour une Charte européenne de l'Audiovisuel. In Dumont; Strowel. (dir.). Politique culturelle et droit de la radio-télévision. Bruxelles: Facultés Universitaires Saint-Louis, p. 43-64.

FERRY, J-M. (2005) Histoire de la Pensee Politique. Syllabus 2004-2005, s/p. Disponível em: http://users.skynet.be/jean.marc.ferry/cours.html Acesso em: 12 mar. 2018.

GENRO, T. A sentença de Moro: "xeque mate" e cheque sem fundos. In: Proner; Cittadino; Ricobom; Dornelles (orgs.). Comentários de uma sentença anunciada. Bauru: Canal 6, 2017, p. 449.

HABERMAS, J. (1981) Teoria do Agir Comunicativo. Vol. 2 Sobre a crítica da razão funcionalista, trad. Flávio Beno Siebeneichler. São Paulo: Martins Fontes, 2012.

GELLNER, E. (1983) Naciones y nacionalismo. Madrid: Alianza Editorial, 2001.

HAN, B-C. (2014) Psicopolitica: Neoliberalismo Y Nuevas Técnicas de Poder, trad. Alfredo Bérges. Barcelona: Herder.

JENKINS, H.; GREEN, J.; FORD, S. (2013) Cultura da Conexão - valor e significado por meio da mídia propagável, trad. Patricia Arnaud. São Paulo: Aleph, 2014.

RINGOOT, R. (2014) Analyser les discours de presse. Paris: Armand Colin.

SANTOS, M. (2000) Por uma outra globalização. Do pensamento único à consciência universal. Rio de Janeiro: Record, 2004.

SOUZA, J. (2016) A Radiografia do Golpe. Entenda como e por que você foi enganado. Rio de Janeiro: Leya, Casa da Palavra.

Recebido: $12 / 03 / 2018$

Aceito: 18/05/2018 